\title{
Research Article \\ Effect of Glass Thickness on Performance of Flat Plate Solar Collectors for Fruits Drying
}

\author{
Ramadhani Bakari, ${ }^{1}$ Rwaichi J. A. Minja, ${ }^{1}$ and Karoli N. Njau ${ }^{2}$ \\ ${ }^{1}$ Department of Chemical and Mining Engineering, University of Dar es Salaam, P.O. Box 35131, Dar es Salaam, Tanzania \\ ${ }^{2}$ The Nelson Mandela African Institute of Science and Technology, Arusha, Tanzania \\ Correspondence should be addressed to Ramadhani Bakari; ramaringo2006@yahoo.co.uk \\ and Rwaichi J. A. Minja; rminja@udsm.ac.tz
}

Received 29 August 2013; Revised 21 January 2014; Accepted 23 January 2014; Published 12 March 2014

Academic Editor: S Venkata Mohan

Copyright ( 2014 Ramadhani Bakari et al. This is an open access article distributed under the Creative Commons Attribution License, which permits unrestricted use, distribution, and reproduction in any medium, provided the original work is properly cited.

\begin{abstract}
This study aimed at investigating the effect of thickness of glazing material on the performance of flat plate solar collectors. Performance of solar collector is affected by glaze transmittance, absorptance, and reflectance which results into major heat losses in the system. Four solar collector models with different glass thicknesses were designed, constructed, and experimentally tested for their performances. Collectors were both oriented to northsouth direction and tilted to an angle of $10^{\circ}$ with the ground toward north direction. The area of each collector model was $0.72 \mathrm{~m}^{2}$ with a depth of $0.15 \mathrm{~m}$. Low iron (extra clear) glass of thicknesses $3 \mathrm{~mm}, 4 \mathrm{~mm}, 5 \mathrm{~mm}$, and $6 \mathrm{~mm}$ was used as glazing materials. As a control, all collector performances were analysed and compared using a glass of $5 \mathrm{~mm}$ thickness and then with glass of different thickness. The results showed that change in glass thickness results into variation in collector efficiency. Collector with $4 \mathrm{~mm}$ glass thick gave the best efficiency of $35.4 \%$ compared to $27.8 \%$ for $6 \mathrm{~mm}$ glass thick. However, the use of glass of $4 \mathrm{~mm}$ thick needs precautions in handling and during placement to the collector to avoid extra costs due to breakage.
\end{abstract}

\section{Introduction}

In many countries, the use of solar drying systems for agricultural products to conserve vegetables, fruits, and other crops has been shown to be practical, inexpensive, and environmentally sound approach [1]. Solar dryers offer a cheaper and an alternative way of processing fruits and vegetables in clean and hygienic condition within international standards. Moreover, they save time, occupy less area, improve product quality, protect the environment, and provide better control of required drying air condition [2]. However, the availability of good information is lacking in many countries, where food-processing systems are mostly needed $[1,3]$. Centrally to that, indirect cabinet dryer with forced convection flow is one of the best drying methods which can produce high-quality products and eliminate the risk of spoilage during drying [4, 5]. Although solar air collector is a very important component in the solar drying system, it has not received much attention during dryer design [6]. In theory, the performance of solar collector depends on climatic conditions and several operating condition such as collector orientation, thickness of cover materials, wind speed, collector length, collector depth, and the type of absorber material used [7-11]. Currently, these factors are not well considered during solar system design. Therefore, development of a well-performed solar collector is of significant economic importance in solar drying system. This study has dealt with the effect of glass thickness on solar collector performance.

\section{Literature Review}

2.1. Flat Plate Solar Collector. Flat plate solar collectors are special kind of heat exchangers that transfer heat energy from incident solar radiation to the working fluid [12-14]. They perform three functions, absorbing solar radiation, converting it to heat energy, and transferring the energy to a working fluid passing through the collector duct [15]. The main use of flat plate solar collectors includes space 
heating and crop drying [16, 17]. Flat plate solar collector can heat working fluid to a temperature range of $10-50^{\circ} \mathrm{C}$ above ambient temperature depending on the design [18]. There are three principal parts of flat plate solar collector: absorber plate which absorbs solar radiation and transfers it to the working fluid, transparent cover which allows short wave radiation to pass and prevents them from exiting, and insulation which resists back and rear side heat losses. The most important advantages of these types of collectors include low construction costs and minimal effect in pressure drops. However, the main drawback of solar air collectors is the low heat transfer coefficient between the absorber plate and the air stream due to poor thermal conductivity and low heat capacity of air [19].

2.2. Glazing Materials. Glazing is the top cover of a solar collector. It performs three major functions in particular: to minimize convective and radiant heat loss from absorber, to transmit the incident solar radiation to the absorber plate with minimum loss, and to protect the absorber plate from outside environment [20,21]. Other important characteristics of glazing materials are reflection $(r)$, absorption $(\alpha)$, and transmission $(\tau)$. In order to attain maximum efficiency, reflection and absorption should be as low as possible, whilst transmission should be as high as possible [22]. Therefore, factors for consideration in selecting the glazing materials include strength of material, durability, nondegradability when exposed to the ultraviolet light (UV), and low costs. Usually the common materials used as glazing materials are glass and plastics.

Glass is the principal material used to glaze solar collectors $[10,13,23,24]$. Glass material has highly desirable property of transmitting as much as $90 \%$ of the incoming short-wave radiation, while virtually none of the long wave radiation emitted by the absorber plate can escape outwards by transmission [25]. To be specific, glass cover for solar collector normally should be at least $0.33 \mathrm{~cm}$ thick [26]. Compared to glass cover, a plastic cover possesses high shortand long-wave transmittance and hence high performance. Generally, the main advantages of plastics are resistance to breakage, light weight, and low cost. However, plastics have been reported to have limited life span due to the effect of UV radiation which reduces its transmissivity [24]. Also, plastics are transparent to long-wavelength radiation and are therefore less effective in reducing radiated heat losses from the absorber plate. In addition, plastics cannot withstand high temperature encountered in collector especially when the collector is idle [26].

\subsection{Influence of Cover Material on the Collector Performance.} The major heat losses in the collector are from the front cover (glass cover), since the sides and the back of the collector are often adequately insulated [24]. Therefore, accurate prediction of the thermal performance of solar collector system strongly depends on how the glass cover material is analysed. Though almost all the studies reported assume that glass cover of a system is transparent for the solar range and opaque for the infrared radiation [27], only few studies have reported on the influence of thickness of glazing materials on the performance of solar collector.
Kalidasa et al., 2008, [28] compared a $3 \mathrm{~mm}$ and $6 \mathrm{~mm}$ glass covers and reported that solar collector with glass cover of $3 \mathrm{~mm}$ thickness was more efficient compared to the collector with $6 \mathrm{~mm}$ glass thickness. Vejen et al. [29] suggest that using a glass cover with better optical properties can improve performance of solar collector by $6 \%$. However, the author did not give the optimal thickness of glass that gives best efficiency.

2.4. Heat Transfer in Glazing Material. Energy absorbed by glass cover depends on temperature difference between glass and fluid, glass and plate, and glass and ambient:

$$
\begin{aligned}
I \cdot \alpha_{g}= & h_{a}\left(T_{g}-T_{a}\right)+h_{f g}\left(T_{c}-T_{f}\right)+h_{r, g p}\left(T_{g}-T_{p}\right) \\
& +h_{r, a g}\left(T_{g}-T_{a}\right) .
\end{aligned}
$$

The radiative heat transfer coefficients from the absorber to the glazing and from the glazing to the ambient are, respectively, given by

$$
\begin{aligned}
& h_{r, g p}=\frac{\sigma\left(T_{g}{ }^{2}+T_{p}{ }^{2}\right)\left(T_{g}+T_{p}\right)}{\left(\left(1 / E_{g}\right)+\left(1 / E_{p}\right)-1\right)}, \\
& h_{r, a g}=\frac{\sigma\left(T_{g}{ }^{2}+T_{a}{ }^{2}\right)\left(T_{g}+T_{a}\right)}{\left(\left(1 / E_{g}\right)-1\right)} .
\end{aligned}
$$

The convective heat transfer coefficients for air flowing over the outside surface of the glass cover were proposed by Kumar and Mullick [30]. Consider

$$
h_{a}=5.7+3.8 V_{w} .
$$

Upward heat losses are greatly influenced by convective heat transfer from the upper outermost surface of a solar collector. This wind induced convective heat transfer has greater influence on upward heat losses in case of single glazed collectors

2.5. General Efficiency of Flat Plate Solar Collectors. The thermal efficiency of a collector is the ratio of the useful thermal energy to the total incident solar radiation averaged over the same time interval. Mathematically, the efficiency $(\eta)$ of a collector is expressed as $[18,31]$

$$
\eta=\frac{\text { useful energy }}{\text { solar energy available }} .
$$

Useful energy for a solar thermal collector is the rate of thermal energy leaving the collector, usually described in terms of the rate of energy being added to a heat transfer fluid passing through the receiver or absorber [13,32]. Consider

$$
Q_{u}=m \cdot C_{p} \cdot\left(T_{o}-T_{i}\right) .
$$

The area of the collector on which the solar irradiance falls is called the aperture area of the collector. Therefore, total 
energy received by collector (optical energy captured) can be described by

$$
Q_{\text {in }}=I \cdot A \text {. }
$$

Accordingly, absorptance and transmittance are multiple effects of optical energy capture and, therefore, these factors indicate the percentage of the solar rays penetrating the transparent cover of the collector and the percentage being absorbed [32]. Consider

$$
\mathrm{Q}_{\text {in }}=\alpha \cdot \tau \cdot I \cdot A .
$$

The rate of useful energy of the collector can be expressed by using overall heat loss coefficient and the collector temperature as (Yogi and Jan, 2000)

$$
\dot{Q}_{\text {useful }}=\dot{Q}_{\text {in }}-\dot{Q}_{\text {loss }}=\alpha \cdot \tau \cdot I \cdot A-U_{L} \cdot A_{C} \cdot\left(T_{c}-T_{a}\right) .
$$

Since, it is difficult to define the collector average temperature in (4). It is convenient to define a quantity that relates the actual useful energy gain of a collector to the useful gain if the whole collector surface were at the fluid inlet temperature [18]. This quantity is known as "the collector heat removal factor $\left(F_{R}\right)$ " and is expressed by

$$
F_{R}=\frac{\dot{m} \cdot C_{p} \cdot\left(T_{o}-T_{i}\right)}{A \cdot\left[\alpha \cdot \tau \cdot I-U_{L} \cdot\left(T_{i}-T_{a}\right)\right]} .
$$

Finally, equation for efficiency of flat plate solar collector can be given by "Hottel-Whillier-Bliss equation" [33]

$$
\eta=F_{R} \cdot \alpha \cdot \tau-F_{R} \cdot U_{L} \cdot\left(\frac{T_{i}-T_{a}}{I_{c}}\right) .
$$

If it is assumed that $\tau$ and $\alpha$ are constants for a given collector and flow rate, then the collector efficiency is a linear function of the three parameters defining the operating condition: solar irradiance $(I)$, fluid inlet temperature $\left(T_{i}\right)$, and collector outlet temperature $\left(T_{o}\right)$. Thus, the performance of a Flat-Plate Collector can be approximated by experimentally measuring these three parameters, and the efficiency can be calculated by using [13]

$$
\eta=\frac{m \cdot C_{p}}{A} *\left[\frac{T_{o}-T_{i}}{I}\right] .
$$

\section{Materials and Methods}

Four similar flat plate solar collectors were used in this study. Glazing materials used for experiments were low iron (extra clear) glass of thicknesses 3, 4, 5, and $6 \mathrm{~mm}$. Collectors were constructed by using Pterocarpus timber (Mninga) of thickness 2 inch and black painted marine plywood as absorbing materials. Additionally, specifications of collectors were collector length to width ratio equal to 2 (length $1.2 \mathrm{~m}$ and width $0.6 \mathrm{~m}$ ) and depth of $0.15 \mathrm{~m}$. Both collectors were oriented to northsouth direction and tilted to an angle of $10^{\circ}$

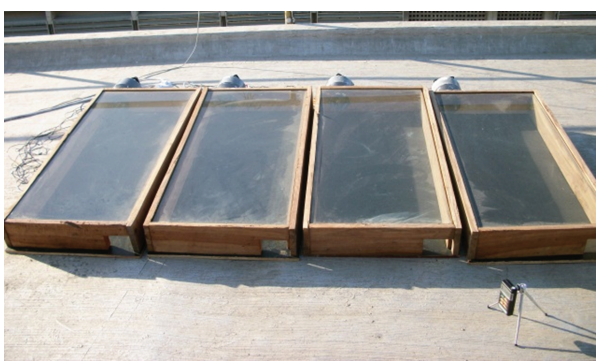

FIGURE 1: Solar collector models with 3, 4, 5, and $6 \mathrm{~mm}$ glass thick, respectively.

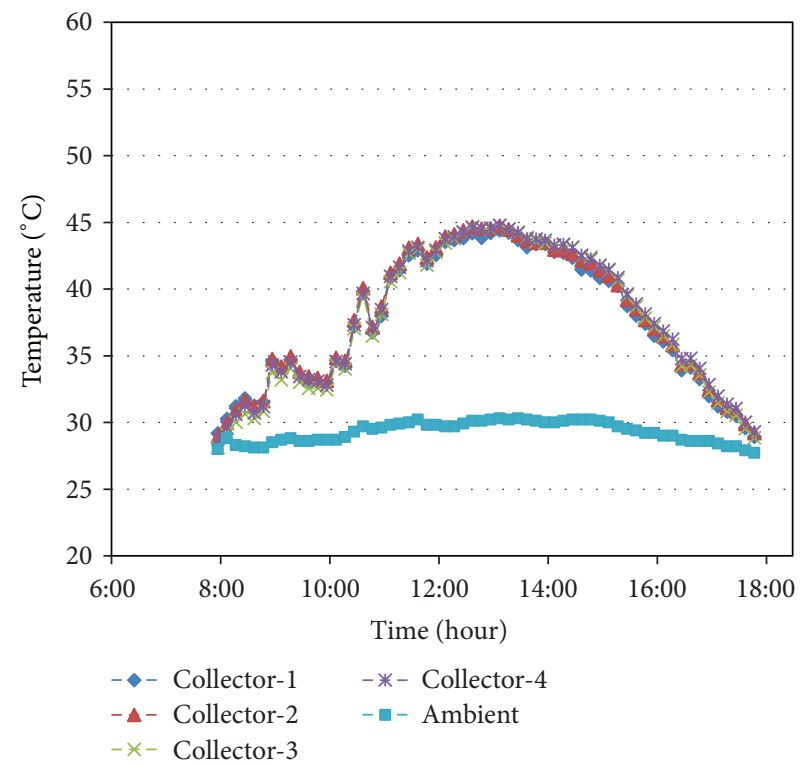

FIGURE 2: Temperature profile of collector with similar glazing thickness.

with the ground toward north direction as shown in Figure 1. Collectors outlet temperatures were measured by using XR5SE data logger connected with PT940 temperature sensors, whilst ambient temperatures were recorded by CEM DT-172 temperature and humidity data logger. On the other hand, solar intensity and air flow rate were, respectively, measured by using PCE-SPM solar radiation meter and Testo $425 \mathrm{Hot}$ Wire Thermal Anemometer. Air flow rate in each collector was controlled by extract fans of capacity $1.27 \mathrm{~m}^{3} / \mathrm{min}$.

Efficiency of the collectors was established by testing each collector with the same glass thickness $(5 \mathrm{~mm})$. The duration for this experiment was 5 days each for collector with similar glazing and with different glazing. Time of experiments was from 7:30 to 6:00 p.m. with an interval of data sampling of 10 minutes. Experiments were conducted at the University of Dar es Salaam at the College of engineering and Technology. Both collector models were placed on top of block Q building situated at the Department of Chemical and Mining Engineering. 
TABLE 1: ANOVA for collector with similar glass thicknesses.

\begin{tabular}{lccccc}
\hline & Sum of squares & df & Mean square & $F$ & Sig. \\
\hline Between groups & 1.427 & 3 & 0.476 & 0.323 \\
Within groups & 4.428 & 12 & 0.369 & \\
\hline Total & 5.854 & 15 & & \\
\hline
\end{tabular}

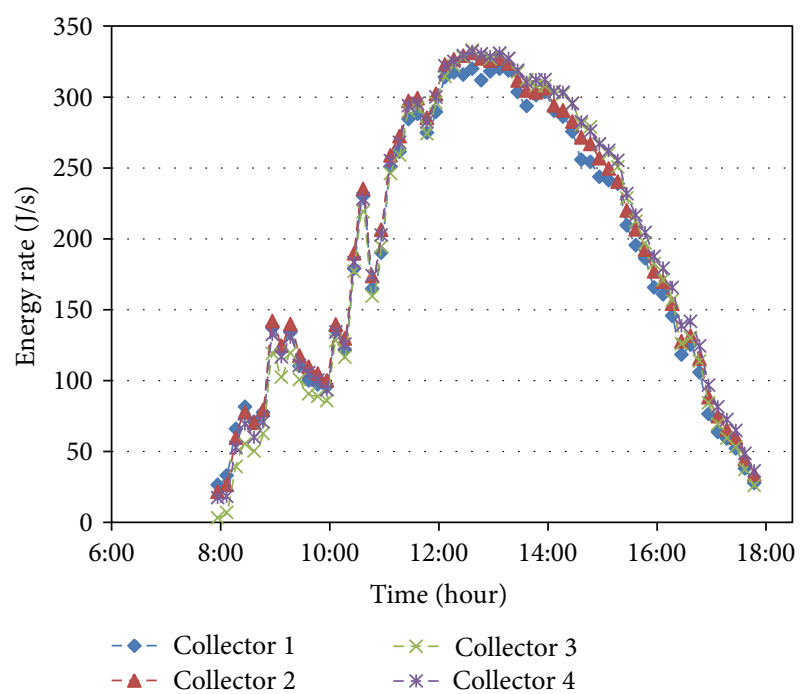

FIGURE 3: Energy profile of collector with similar glazing thickness.

\section{Results and Discussion}

4.1. Collector with the Same Glass Thickness. The main objective of this experiment was to find out if there is significance performances difference between designed collector models with similar characteristics. Each collector model was tested for its performance by using $5 \mathrm{~mm}$ glass thickness.

4.1.1. Temperature and Energy Profile of Collectors with Same Glass Thickness. Figure 2 shows the variation of ambient and outlet temperature of four collector models recorded from 7:30 a.m. to 06:00 p.m. on September 12, 2011, while Figure 3 shows the rate of flow of energy.

From Figure 2, it can be seen that there is no variation in temperature between collectors; however, temperature varies according to the fluctuation of solar intensity. Fluctuations of temperature during the morning are high when compared to afternoon due to high clouds coverage which results in low solar intensity reaching the earth. Similar characteristics were observed in energy profile in Figure 3. The efficiencies of the solar collectors were evaluated by finding the area under energy curve. Statistical analysis of the thermal efficiency of solar air collectors with the same thickness glazing materials was analysed with SPSS program with confidence interval of $95 \%$. Efficiency means of collector models 1, 2, 3, and 4 were $29.6 \%, 29.8 \%, 30.3 \%$, and $30.3 \%$, respectively. A one-way between-subjects ANOVA (analysis of variance) was used to compare the efficiencies of the collector models and reported

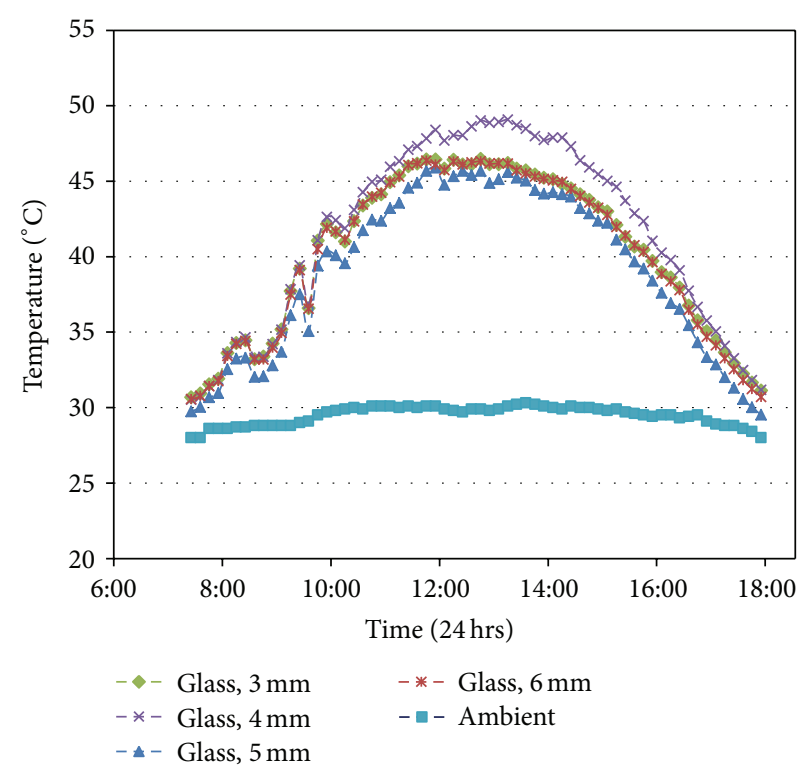

FIGURE 4: Temperature profiles of collector with different glass thicknesses on 17/10/2011.

in Table 1. The main objective was to determine if there is a significance difference between collectors' efficiencies when operated with the same glazing materials.

From Table 1, the significance value is $0.323(P<0.05)$. Therefore; it can be concluded that there were no statistically significant differences between the means of collector efficiency with the same glass thickness and that their minor variations were due to changes in environmental conditions and not due to design variations.

\subsection{Collectors with the Different Glass Thicknesses}

4.2.1. Temperature and Energy Profile of Collectors with Different Glass Thicknesses. Figure 4 shows temperature profiles trends of ambient and outlet temperature for four collector models recorded from 7:30 a.m. to 06:00 p.m. on 5/10/2011. It can be seen that, during sun rise to noon, there were high temperature fluctuations mostly due to variations in solar intensity and these fluxes appear to be steady from noon to sunset. On other hand, solar collector delivers low temperature from morning to noon session, while solar intensity was high as a consequence of low angle of incidence on collector surfaces (Figure 5). Das and Chakraverty [34] reported the decrease in solar transmittance to the surface of the glass to be significance for angle between 0 and $60^{\circ}$. Similar characteristics also can be observed during afternoon session. 
TABLE 2: Statistical analysis of performance of solar collectors with different glass thicknesses by using SPSS program.

\begin{tabular}{|c|c|c|c|c|c|c|c|c|}
\hline \multirow{2}{*}{ Glass } & \multirow{2}{*}{$N$} & \multirow{2}{*}{ Mean } & \multirow{2}{*}{$\begin{array}{l}\text { Standard } \\
\text { deviation }\end{array}$} & \multirow{2}{*}{$\begin{array}{l}\text { Standard } \\
\text { error }\end{array}$} & \multicolumn{2}{|c|}{$95 \%$ confidence interval for mean } & \multirow{2}{*}{ Minimum } & \multirow{2}{*}{ Maximum } \\
\hline & & & & & Lower bound & Upper bound & & \\
\hline Glass, $3 \mathrm{~mm}$ & 5 & 32.7400 & 3.63015 & 1.62345 & 28.2326 & 37.2474 & 26.50 & 35.80 \\
\hline Glass, $4 \mathrm{~mm}$ & 5 & 35.4000 & 4.07001 & 1.82016 & 30.3464 & 40.4536 & 28.50 & 38.60 \\
\hline Glass, $5 \mathrm{~mm}$ & 5 & 30.4400 & 2.40583 & 1.07592 & 27.4528 & 33.4272 & 27.30 & 33.70 \\
\hline Glass, $6 \mathrm{~mm}$ & 5 & 27.8000 & 2.43002 & 1.08674 & 24.7827 & 30.8173 & 24.40 & 31.20 \\
\hline Total & 20 & 31.5950 & 4.12546 & 0.92248 & 29.6642 & 33.5258 & 24.40 & 38.60 \\
\hline \multicolumn{9}{|l|}{ Model } \\
\hline Fixed effects & & & 3.21854 & 0.71969 & 30.0693 & 33.1207 & & \\
\hline Random effects & & & & 1.62083 & 26.4368 & 36.7532 & & \\
\hline
\end{tabular}

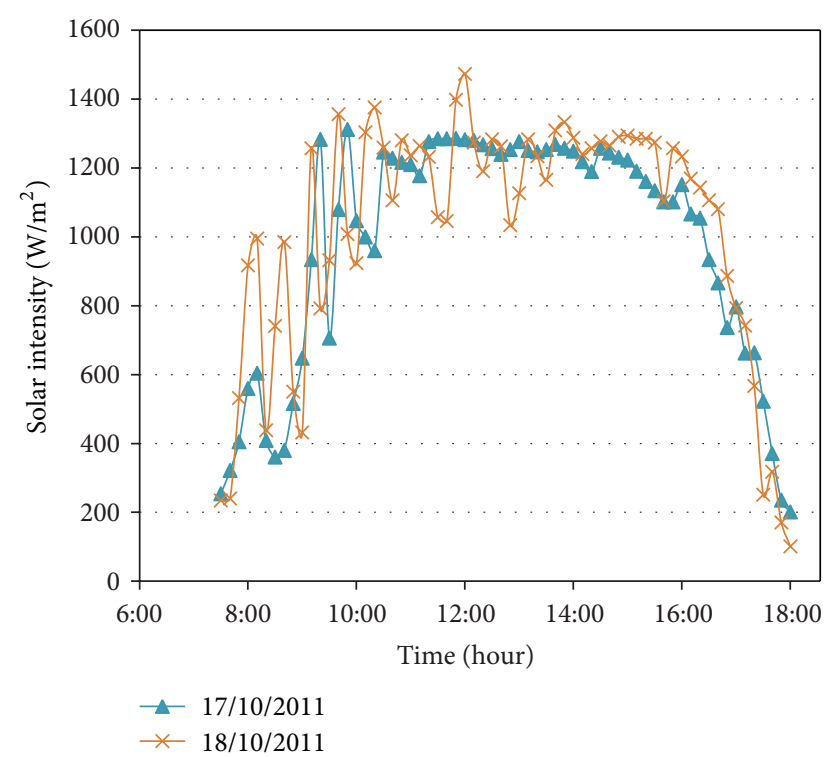

FIGURE 5: Solar intensity on 17/10/2011 and 18/10/2011.

Maximum temperature in both collectors occurred around noon when solar radiations were perpendicular to the collector surfaces. With single orientation of flat plate solar collector, the best performance occurs when the solar radiations are perpendicular to the collector surfaces, for this case at around noon.

Figure 6 shows energy profiles; the energy profiles varied with fluctuation of solar intensity and were increased with increasing solar intensity. Low energy during the morning and during the evening was caused by poor angle of solar intensity incidence on collector surface. In addition, slight fluctuations in energy profile during the afternoon were due to poor thermal heat storage behaviour of marine board.

The collector efficiency was evaluated by finding the area under the energy profiles curve and statistically tested for their difference. The results of the statistical analysis of variance (ANOVA) for collectors with different glass thickness were carried out to study the significance differences between their individual means and are reported in Table 2.

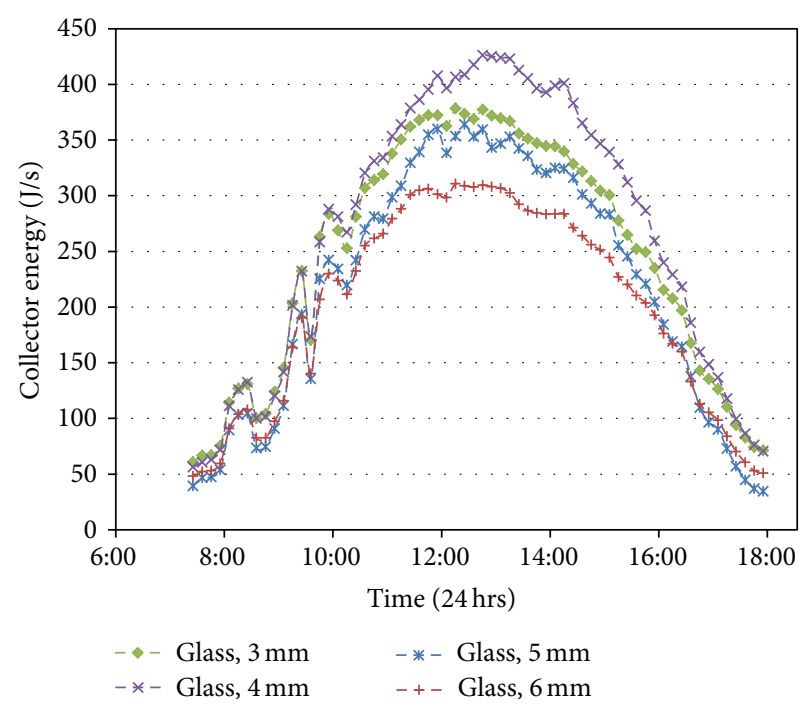

FIGURE 6: Energy profile of collectors with different glass thickness on October 17, 2011.

The highest thermal efficiency as analysed by SPSS program was $35.4 \%$ in collector with $4 \mathrm{~mm}$ glass thickness, while the minimum performance was $27.8 \%$ in collector with $6 \mathrm{~mm}$ glass thickness. Collectors with $3 \mathrm{~mm}$ and $5 \mathrm{~mm}$ glass thicknesses were $32.7 \%$ and $30.4 \%$, respectively. In the same way, a one-way between-subjects ANOVA was used to compare the effect of varying the thickness of glass materials on efficiency of collectors with $3,4,5$, and $6 \mathrm{~mm}$ glass thicknesses. This was done to ascertain if the difference between collector's means were significant.

From Table 3 , it can be seen that significance value is $P=$ 0.012 . Therefore, it could statistically be concluded that there were significant differences between the means of collector efficiency with different glass thicknesses. Thus, in order to identify which thickness of glass gave significant difference, a post hoc test for multiple comparisons of the collector efficiencies was conducted. Since there were two possibility tests to occur: equal variances assumed or equal variances not assumed, Levene test for homogeneity of variance was used to decide the method to use (see Table 4). 
TABLE 3: ANOVA for collectors with different glass thicknesses.

\begin{tabular}{lccccc}
\hline & Sum of squares & df & Mean square & $F$ & 5.072 \\
\hline Between groups & 157.625 & 3 & 52.542 & Significance \\
Within groups & 165.744 & 16 & 10.359 & 0.012 \\
\hline Total & 323.369 & 19 & & \\
\hline
\end{tabular}

TABLE 4: Results for Levene test for homogeneity of variance.

\begin{tabular}{lccc}
\hline Levene statistic & df1 & df2 & Significance \\
\hline 0.462 & 3 & 16 & 0.713 \\
\hline
\end{tabular}

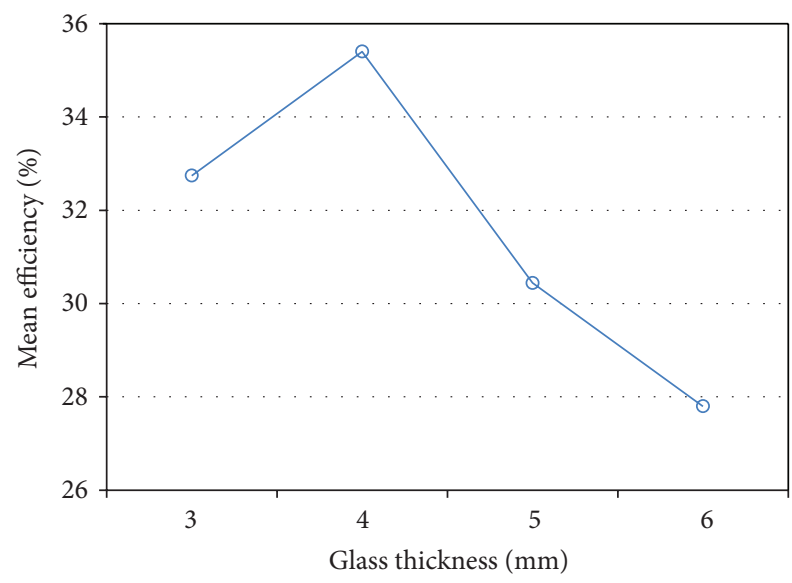

FIGURE 7: Means plot of performances of solar collectors with different glass thicknesses.

Since, from Table 3, $P>0.05$, equal variances assumed (Tukey HSD) test was used.

Table 5 shows equal variances assumed (Tukey HSD) for multiple comparisons of the collector efficiencies. The multiple comparison test shows that collector with glass thickness $4 \mathrm{~mm}$ had statistically performed differently from collectors with glass thickness of $6 \mathrm{~mm}(P<0.05)$. Therefore, it can be concluded that, using glass thickness of $4 \mathrm{~mm}$, thickness improves the performance of the flat plate solar collector by $7.6 \%$ as compared to $6 \mathrm{~mm}$ glass thickness. The effect of the glass thickness can clearly be depicted in Figure 7, whereby collector with $6 \mathrm{~mm}$ thickness gave poor performance, while $4 \mathrm{~mm}$ thickness gave the best performance. Khoukhi et al. [27] reported that, on increasing the thickness of the glass cover from $3 \mathrm{~mm}$ to $6 \mathrm{~mm}$, the steady heat flux through the cover decreases and, therefore, thinner glass $(3 \mathrm{~mm})$ is more suitable with regard to the cost and the weight of the solar collector system when compared to $6 \mathrm{~mm}$ thickness. These results also support the conclusion given by Vejen et al. [29] who outlines good selection of glazing materials as one of the factors that can improve the performance of solar collector. The study shows that performance of collector can be improved by $6 \%$ or more when thick and thin glasses are compared.
Thermal properties of glass cover such as transmittance, reflectance, and absorptance are functions of collector performance. Therefore, the choice of collector glazing material should focus on increasing transmittance and reducing reflectance and absorbance. Generally, when increasing glass thickness, transmittance and convective losses decrease, while reflectance increases and vice versa. From this study, it can be concluded that $3 \mathrm{~mm}$ glass thickness gives high transmittance (low reflectance) and high convective losses and hence is worse performance compared to $4 \mathrm{~mm}$. The $5 \mathrm{~mm}$ and $6 \mathrm{~mm}$ glass thicknesses gave low transmittance (high reflectance) and low convective losses and therefore gave poor performances compared to $4 \mathrm{~mm}$ glass thickness. Therefore, $4 \mathrm{~mm}$ glass thickness gave optimal transmittance and convective losses, and hence is the best glazing thickness for flat plate solar collector.

\section{Conclusion}

The solar collector models with different glazing thicknesses had been successfully designed, constructed, and tested in this study. The experimental data were compared graphically by using excel program and their performances were analysed statistically by using SPSS programme. From the results obtained, it could be concluded that the use of $4 \mathrm{~mm}$ glass thick improves the performance of air solar collector by $7.6 \%$ compared to 3, 5, and $6 \mathrm{~mm}$ glass thicknesses. However, the risk for glass breakage during construction is high when using thinner glass, $4 \mathrm{~mm}$ compared to $5 \mathrm{~mm}$ and $6 \mathrm{~mm}$, especially when constructing larger collector with longer/wider span. Therefore, optimization of efficiency and runability owe to be made on whether to use $4 \mathrm{~mm}$ glass thickness with precaution to avoid extra cost due to glass breakage.

\section{Nomenclature}

A: Collector area $\left(\mathrm{m}^{2}\right)$

$F_{R}$ : Collector heat removal factor

$C_{p}:$ Specific heat capacity of air $(\mathrm{J} / \mathrm{Kg} \cdot \mathrm{K})$

$m$ : Mass flow rate $(\mathrm{kg} / \mathrm{s})$

I: Global solar intensity reaching collector surface $\left(\mathrm{W} / \mathrm{m}^{2}\right)$

$Q_{u}$ : Useful energy gained by air $(\mathrm{J} / \mathrm{Kg} \cdot \mathrm{K})$

$Q_{\text {in }}$ : Available solar energy on collector surface $(\mathrm{J} / \mathrm{Kg} \cdot \mathrm{K})$

$T_{o}$ : Temperature out of collector $\left({ }^{\circ} \mathrm{C}\right)$

$T_{i}$ : Air inlet temperature $\left({ }^{\circ} \mathrm{C}\right)$

$U_{L}$ : Heat loss coefficient $\left(\mathrm{W} / \mathrm{m}^{2} \mathrm{~K}\right)$

$\alpha$ : Absorptivity 
TABLE 5: Multiple comparisons test for collector mean efficiencies.

\begin{tabular}{|c|c|c|c|c|c|c|}
\hline \multirow{2}{*}{ (I) Glass } & \multirow{2}{*}{ (J) Glass } & \multirow{2}{*}{ Mean difference $(\mathrm{I}-\mathrm{J})$} & \multirow{2}{*}{ Standard error } & \multirow{2}{*}{ Significance } & \multicolumn{2}{|c|}{$95 \%$ confidence interval } \\
\hline & & & & & Lower bound & Upper bound \\
\hline \multirow{3}{*}{ Glass, $3 \mathrm{~mm}$} & Glass, $4 \mathrm{~mm}$ & -2.66000 & 2.03558 & 0.572 & -8.4838 & 3.1638 \\
\hline & Glass, $5 \mathrm{~mm}$ & 2.30000 & 2.03558 & 0.677 & -3.5238 & 8.1238 \\
\hline & Glass, $6 \mathrm{~mm}$ & 4.94000 & 2.03558 & 0.112 & -0.8838 & 10.7638 \\
\hline \multirow{3}{*}{ Glass, $4 \mathrm{~mm}$} & Glass, $3 \mathrm{~mm}$ & 2.66000 & 2.03558 & 0.572 & -3.1638 & 8.4838 \\
\hline & Glass, $5 \mathrm{~mm}$ & 4.96000 & 2.03558 & 0.110 & -0.8638 & 10.7838 \\
\hline & Glass, 6 mm & $7.60000^{*}$ & 2.03558 & 0.009 & 1.7762 & 13.4238 \\
\hline \multirow{3}{*}{ Glass, $5 \mathrm{~mm}$} & Glass, $3 \mathrm{~mm}$ & -2.30000 & 2.03558 & 0.677 & -8.1238 & 3.5238 \\
\hline & Glass, $4 \mathrm{~mm}$ & -4.96000 & 2.03558 & 0.110 & -10.7838 & 0.8638 \\
\hline & Glass, $6 \mathrm{~mm}$ & 2.64000 & 2.03558 & 0.578 & -3.1838 & 8.4638 \\
\hline \multirow{3}{*}{ Glass, $6 \mathrm{~mm}$} & Glass, $3 \mathrm{~mm}$ & -4.94000 & 2.03558 & 0.112 & -10.7638 & 0.8838 \\
\hline & Glass, $4 \mathrm{~mm}$ & $-7.60000^{*}$ & 2.03558 & 0.009 & -13.4238 & -1.7762 \\
\hline & Glass, $5 \mathrm{~mm}$ & -2.64000 & 2.03558 & 0.578 & -8.4638 & 3.1838 \\
\hline
\end{tabular}

${ }^{*}$ The mean difference is significant at the 0.05 level.

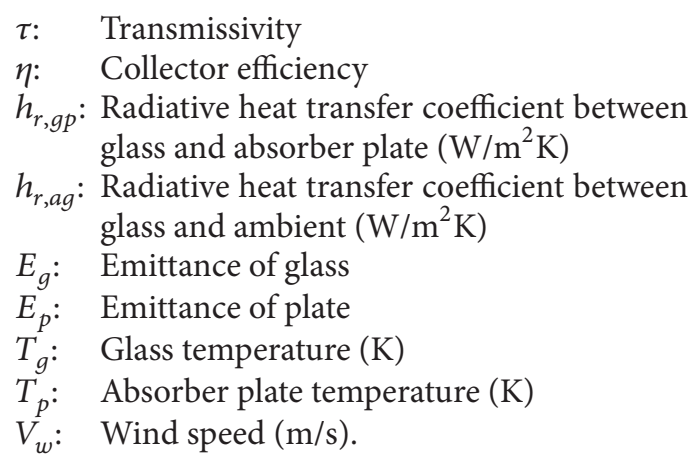

\section{Conflict of Interests}

The authors declare that there is no conflict of interests regarding the publication of this paper.

\section{Acknowledgments}

The authors wish to acknowledge the financial support from the Sida-UDSM-Food Security Programme Research Funds which is part of the Sida-UDSM Cooperation Programme for the period of 2009 to 2013.

\section{References}

[1] A. Sharma, C. R. Chen, and N. V. Lan, "Solar-energy drying systems: a review," Renewable and Sustainable Energy Reviews, vol. 13, no. 6-7, pp. 1185-1210, 2009.

[2] D. R. Pangavhane, R. L. Sawhney, and P. N. Sarsavadia, "Design, development and performance testing of a new natural convection solar dryer," Energy, vol. 27, no. 6, pp. 579-590, 2002.

[3] A. Sreekumar, P. E. Manikantan, and K. P. Vijayakumar, "Performance of indirect solar cabinet dryer," Energy Conversion and Management, vol. 49, no. 6, pp. 1388-1395, 2008.

[4] L. Bennamoun and A. Belhamri, "Design and simulation of a solar dryer for agriculture products," Journal of Food Engineering, vol. 59, no. 2-3, pp. 259-266, 2003.
[5] G. Mulokozi, L. Mselle, C. Mgoba, J. Mugyabuso, and G. Ndossi, Improved Solar Drying of Vitamin A-Rich Foods by Women's groups in the Singida District of Tanzania, vol. 5, International Center for Research on Women, 2000.

[6] M. A. Karim and M. N. A. Hawlader, "Development of solar air collectors for drying applications," Energy Conversion and Management, vol. 45, no. 3, pp. 329-344, 2004.

[7] E. K. Akpinar and F. Koçyiĝit, "Energy and exergy analysis of a new flat-plate solar air heater having different obstacles on absorber plates," Applied Energy, vol. 87, no. 11, pp. 3438-3450, 2010.

[8] M. Ben-Amara, I. Houcine, A.-A. Guizani, and M. Maalej, "Efficiency investigation of a new-design air solar plate collector used in a humidification-dehumidification desalination process," Renewable Energy, vol. 30, no. 9, pp. 1309-1327, 2005.

[9] M. F. El-khawajah, L. B. Y. Aldabbagh, and F. Egelioglu, "The effect of using transverse fins on a double pass flow solar air heater using wire mesh as an absorber," Solar Energy, vol. 85, no. 7, pp. 1479-1487, 2011.

[10] A. E. Kabeel and S. A. El-Agouz, "Review of researches and developments on solar stills," Desalination, vol. 276, no. 1-3, pp. 1-12, 2011.

[11] B. Kundu, "Analytic method for thermal performance and optimization of an absorber plate fin having variable thermal conductivity and overall loss coefficient," Applied Energy, vol. 87, no. 7, pp. 2243-2255, 2010.

[12] B. Brenndorfer, L. Kennedy, C. O. O. Bateman, D. Trim, and G. Mrema, Solar Dryers: Their Role in Post-Harvest Processing, Commonwealth Secretariat, 1985.

[13] O. V. Ekechukwu and B. Norton, "Review of solar-energy drying systems III: low temperature air-heating solar collectors for crop drying applications," Energy Conversion and Management, vol. 40, no. 6, pp. 657-667, 1999.

[14] D. Alta, E. Bilgili, C. Ertekin, and O. Yaldiz, "Experimental investigation of three different solar air heaters: energy and exergy analyses," Applied Energy, vol. 87, no. 10, pp. 2953-2973, 2010.

[15] S. A. Kalogirou, "Solar thermal collectors and applications," Progress in Energy and Combustion Science, vol. 30, no. 3, pp. 231-295, 2004. 
[16] L. B. Y. Aldabbagh, F. Egelioglu, and M. Ilkan, "Single and double pass solar air heaters with wire mesh as packing bed," Energy, vol. 35, no. 9, pp. 3783-3787, 2010.

[17] J. Gordon, Solar Energy: The State of the Art: ISES Position Papers, Earthscan/James \& James, 2001.

[18] F. Struckmann, "Analysis of flat-plate solar collector," Project Report MVK160, Heat and Mass Transport, Lund, Sweden, 2008.

[19] A. A. El-Sebaii, S. Aboul-Enein, M. R. I. Ramadan, S. M. Shalaby, and B. M. Moharram, "Thermal performance investigation of double pass-finned plate solar air heater," Applied Energy, vol. 88, no. 5, pp. 1727-1739, 2011.

[20] F. DeWinter, Solar Collectors, Energy Storage, and Materials, vol. 5, The MIT Press, 1990.

[21] G. S. E. Society, Planning and Installing Solar Thermal Systems: A Guide for Installers, Architects and Engineers, Earthscan/James \& James, 2009.

[22] V. Quaschning, Understanding Renewable Energy Systems, Earthscan/James \& James, 2005.

[23] M. A. Leon, S. Kumar, and S. C. Bhattacharya, "A comprehensive procedure for performance evaluation of solar food dryers," Renewable and Sustainable Energy Reviews, vol. 6, no. 4, pp. 367393, 2002.

[24] I. V. Ion and J. G. Martins, Design, Developing and Testing of a Solar Air Collector, Glass, University of Minho, 2006.

[25] P. Rhushi Prasad, H. V. Byregowda, and P. B. Gangavati, "Experiment analysis of flat plate collector and comparison of performance with tracking collector," European Journal of Scientific Research, vol. 40, no. 1, pp. 144-155, 2010.

[26] P. Garg and J. Prakash, Solar Energy: Fundamental and Application, Tata McGraw-Hill, New Delhi, India, 2006.

[27] M. Khoukhi and S. Maruyama, "Theoretical approach of a flatplate solar collector taking into account the absorption and emission within glass cover layer," Solar Energy, vol. 80, no. 7, pp. 787-794, 2006.

[28] K. Kalidasa Murugavel, K. K. S. K. Chockalingam, and K. Srithar, "Progresses in improving the effectiveness of the single basin passive solar still," Desalination, vol. 220, no. 1-3, pp. 677686, 2008.

[29] N. K. Vejen, S. Furbo, and L. J. Shah, "Development of $12.5 \mathrm{~m}^{2}$ solar collector panel for solar heating plants," Solar Energy Materials and Solar Cells, vol. 84, no. 1-4, pp. 205-223, 2004.

[30] S. Kumar and S. C. Mullick, "Wind heat transfer coefficient in solar collectors in outdoor conditions," Solar Energy, vol. 84, no. 6, pp. 956-963, 2010.

[31] D. Luna, Y. Jannot, and J.-P. Nadeau, "An oriented-design simplified model for the efficiency of a flat plate solar air collector," Applied Thermal Engineering, vol. 30, no. 17-18, pp. 2808-2814, 2010.

[32] S. Farahat, F. Sarhaddi, and H. Ajam, "Exergetic optimization of flat plate solar collectors," Renewable Energy, vol. 34, no. 4, pp. 1169-1174, 2009.

[33] S. Karatasou, M. Santamouris, and V. Geros, "On the calculation of solar utilizability for south oriented flat plate collectors tilted to an angle equal to the local latitude," Solar Energy, vol. 80, no. 12, pp. 1600-1610, 2006.

[34] S. Das and A. Chakraverty, "Performance of a solar collector with different glazing materials and their degradation under the condition prevailing in a solar collector," Energy Conversion and Management, vol. 31, no. 3, pp. 233-242, 1991. 


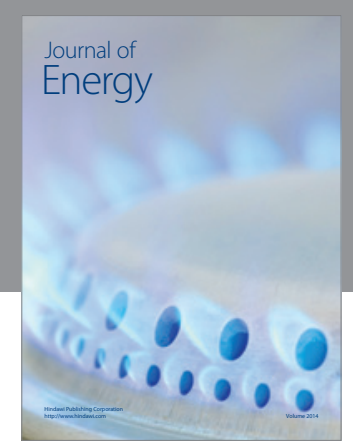

Journal of

Industrial Engineering
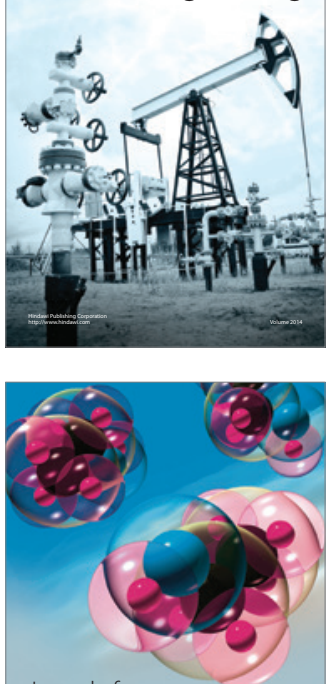

Fuels
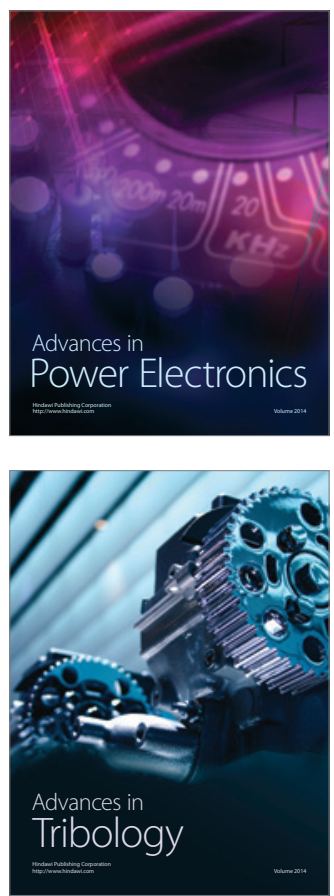

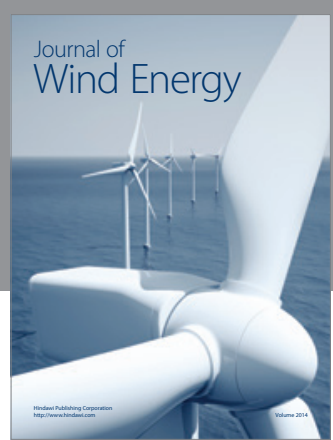

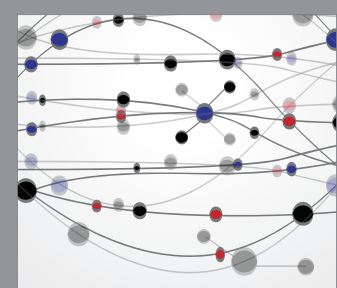

The Scientific World Journal

Submit your manuscripts at http://www.hindawi.com

Journal of

Structures
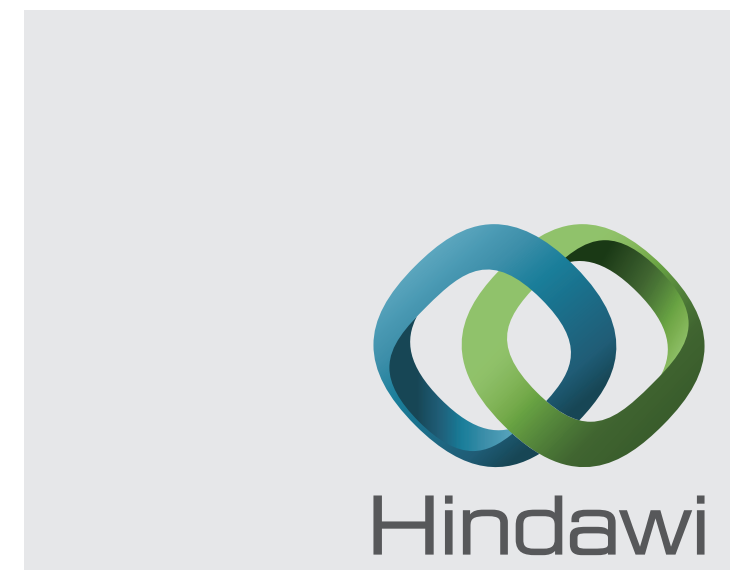

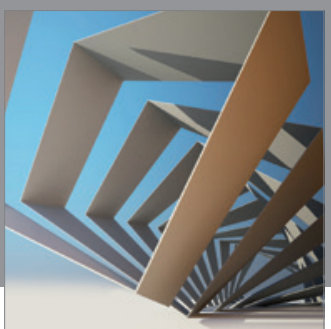

Rotating

Machinery
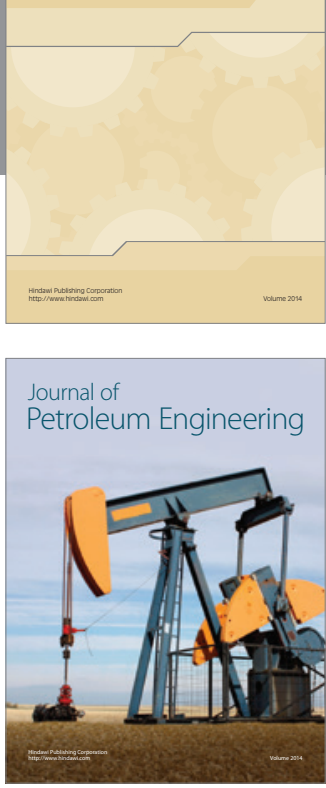

Journal of

Solar Energy
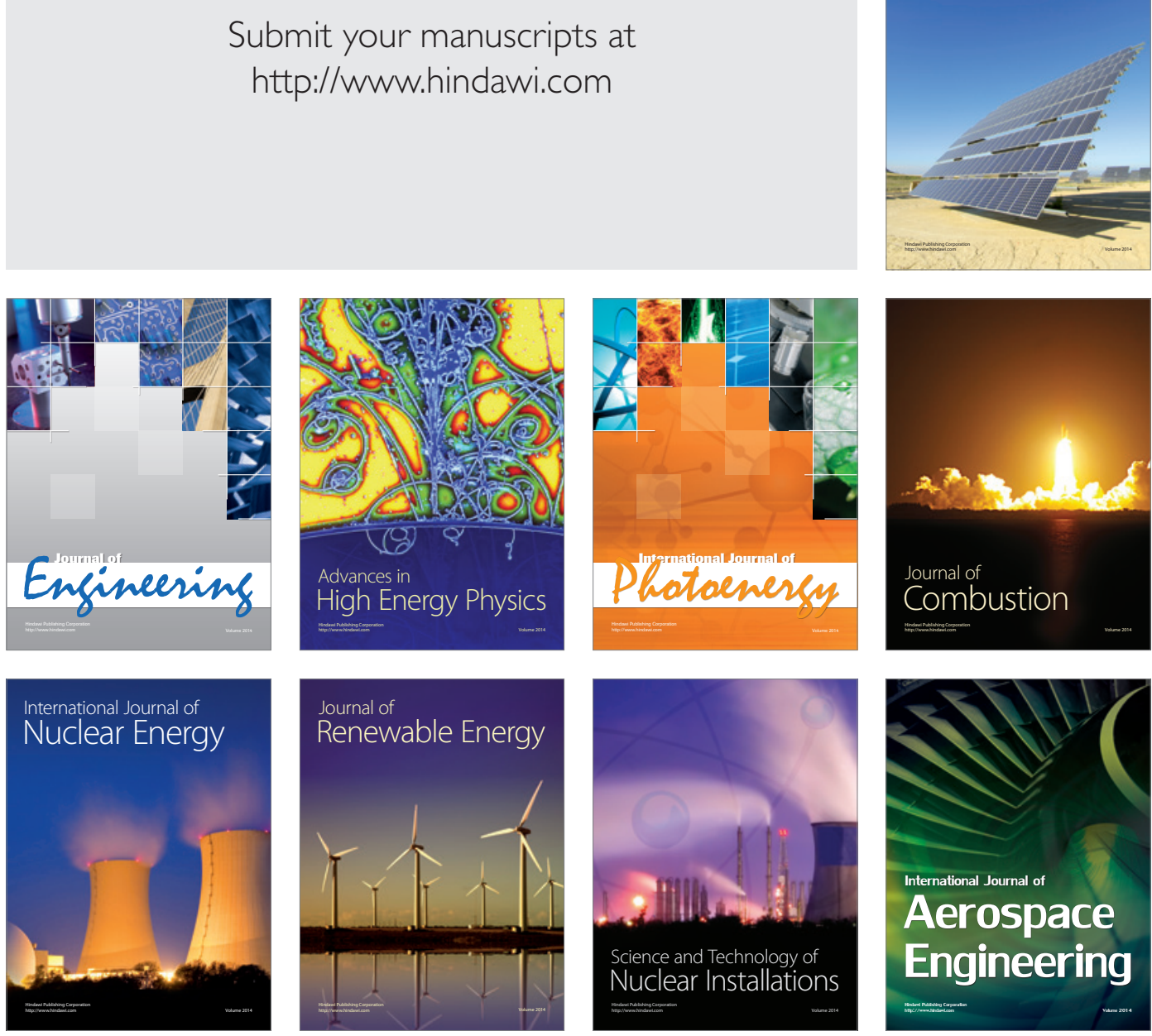